\title{
Racial attitudes and voting behavior in the 1988 national elections: Liberals versus conservatives
}

\author{
RUSSELL EISENMAN and HENRY B. SIRGO \\ McNeese State University, Lake Charles, Louisiana
}

\begin{abstract}
To further investigate liberals versus conservatives, data on racial attitudes are related to voting behavior in the 1988 national elections for President of the United States and for races for the U.S. Senate and for the House of Representatives. The sample size ranged from 537 to 1,154 people surveyed in a national representative sample of voters. Results link conservatism to belief that the government should not help blacks and/or that the civil rights movement is pushing too fast for their goals. Liberals are more favorable to helping blacks. The data are consistent with previous findings linking conservatism and prejudice, and contradict the view that racial attitudes do not relate to behavior.
\end{abstract}

Racial attitudes appear to be extremely important in determining voting behavior. According to Carmines and Stimson $(1980,1989)$, race is the only issue to arise since the Roosevelt New Deal that has had a major effect on voting behavior in national elections. This view goes counter to the position of Ray (1984), who maintains that racial attitudes do not necessarily affect behavior. Ray cites the work of LaPierre (1934) and himself (Ray, 1971, 1976) to argue that racial attitudes are often unrelated to discriminatory behavior. This seems like a surprising position, and is inconsistent with more recent work showing a link between holding conservative beliefs on the one hand and having racially discriminatory beliefs on the other (Eisenman, 199lb; Eisenman \& Sirgo, 1991; Sirgo \& Eisenman, 1990). That is, conservatives have been found to hold certain beliefs about social and political issues, including race, and they also believe in discrimination against people on the basis of race. While not all conservatives have to fit this profile, the above-mentioned studies did support this result, which would suggest that there is a relationship between conservative attitudes and discrimination. For example, Eisenman (1991b) found that college women who identified themselves as conservatives said that an African-American should not be President of the United States. One would think that such

The authors gratefully acknowledge funding by the Shearman Research Initiative Fund, which made the production of this work possible. The data utilized in this study were made possible by the Inter-university Consortium for Political and Social Research. Neither the original collectors of the data nor the Consortium bear any responsibility for the analysis or the interpretations presented here. A modified version of this paper was presented at the annual meeting of the Southwestern Social Science Association, Austin, Texas, March 1991. For correspondence or reprint requests, the addresses of the authors are: R. Eisenman, Department of Psychology, McNeese State University, Lake Charles, LA 70609-1895, and H. B. Sirgo, Department of Social Sciences, McNeese State University, Lake Charles, LA 70609-2335. women, if they vote or express themselves in other ways, would not be inclined to favor blacks or policies that would be helpful to blacks. Likewise, the whites in Louisiana showed a preference for David Duke in U.S. Senate and Gubernatorial elections, despite his Ku Klux Klan and Nazi background (Eisenman, 1992). The attitudes of students toward Duke predicted his white vote in the U.S. Senate election of October 1990 (Eisenman, 1992). Eisenman (1993) found supportive results; Sirgo and Eisenman (1993) found that conservatives had more favorable attitudes toward government than did liberals, perhaps because, while governments have given some support to minorities, it is not so much as to please liberals or to totally offend conservatives.

From the above, it would seem that racial attitudes might be related to voting behavior, although Ray (1984) might say that this is not necessarily the case. The present study was designed to sample voters throughout the United States to see how their racial attitudes related to their voting behavior in the U.S. Senate, House of Representatives, and Presidential elections of 1988. From the more recent studies cited, it would seem likely that racial attitudes would have an influence on voting behavior. Since Eisenman and Sirgo (1991) found that conservatives tend to be Republicans and liberals tend to be Democrats, it was deemed important to study the voting behavior and racial attitudes as related to party or candidate preference.

\section{METHOD}

\footnotetext{
Subjects

A nationwide survey sample of registered voters in the 1988 national elections for U. S. Senate, U. S. House of Representatives, and the Presidential election was carried out by the Institute for Survey Research, University of Michigan, as part of a larger survey of voters. This was a representative sample, to fit the demographic characteristics of 1988 voters. The sample sizes for the various data reported here range from 537 to 1,154 voters. Respondents were surveyed at their households,
} 
and a $71 \%$ response rate was achieved. The sampling was based on U.S. Census districts and included all of the United States except Alaska and Hawaii. To be included, a subject had to be at least 18 years of age and a United States citizen on or before November 8, 1988. People living on military reservations were also excluded.

\section{Procedure}

The interviewees were asked if the government should help blacks. Their answers were rated on a 7-point scale by trained raters, ranging from a score of 1 (The government should help blacks) to a score of 7 (blacks should help themselves). Also, a question was asked about whether civil rights leaders have been trying to push too fast for their goals, and answers to this were categorized into three categories: too fast, about right, or too slowly.

\section{RESULTS}

The results are summarized in Tables 1-4. Tables 1-3 report the findings for the question of whether or not the government should help blacks, as related to votes for the Democratic or Republican candidates in the U.S. House of Representatives and Senate races, and votes for George Bush or Michael Dukakis in the Presidential race. Table 4 is on how are civil rights leaders pushing (too fast, about right, or too slowly) in relation to voting for Bush or Dukakis. In all instances, those who could be thought of as conservatives or sympathetic to the more conservative candidate were more negative toward governmental help for blacks than were those who were not conservatively oriented.

\section{DISCUSSION}

The results support the notion of a relationship between support of Republican candidates and anti-black attitudes or, to say it differently, being less willing to support government help of blacks. In the House,

Table 1

Should Government Help Blacks Scale by Vote for President, 1988

\begin{tabular}{ccc}
\hline Ratings & Bush & Dukakis \\
\hline 1 & 8 & 29 \\
2 & 6 & 20 \\
3 & 19 & 38 \\
4 & 84 & 68 \\
5 & 58 & 28 \\
6 & 48 & 29 \\
7 & 64 & 38
\end{tabular}

Note-1 = Government should help blacks, 7 = Blacks should help themselves. $\chi^{2}(6)=46.93, p<.000001$.

Table 2

Should Government Help Blacks Scale by Vote for U. S. House, 1988

\begin{tabular}{ccc}
\hline Ratings & Democrats & Republicans \\
\hline 1 & 27 & 3 \\
2 & 14 & 7 \\
3 & 36 & 13 \\
4 & 84 & 54 \\
5 & 41 & 34 \\
6 & 39 & 29 \\
7 & 49 & 43 \\
\hline
\end{tabular}

Note-1 = Government should help blacks, $7=$ Blacks should help themselves. $\chi^{2}(6)=18.09, p=.006$.
Table 3

Should Government Help Blacks Scale by Vote for U. S. Senate, 1988

\begin{tabular}{ccc}
\hline Ratings & Republicans & Democrats \\
\hline 1 & 19 & 3 \\
2 & 14 & 5 \\
3 & 30 & 15 \\
4 & 57 & 51 \\
5 & 29 & 30 \\
6 & 27 & 30 \\
7 & 33 & 38 \\
\hline
\end{tabular}

Note-1 = Government should help blacks, $7=$ Blacks should help themselves. $\chi^{2}(6)=18.34, p=.0054$.

Table 4

How Are Civil Rights Leaders Pushing by Vote for President, 1988

\begin{tabular}{lcc}
\hline & Bush & Dukakis \\
\hline Too Fast & 200 & 94 \\
About Right & 375 & 311 \\
Too Slowly & 33 & 141 \\
\hline
\end{tabular}

Note $-\chi^{2}(2)=108.20, p<.00001$.

Senate, and Presidential elections, voters who support the Republican candidate are likely to believe the government should not help blacks, while voters who support the Democratic candidate tend to believe the government should help blacks. Likewise, supporters of George Bush were likely to say that civil rights leaders are pushing too fast, while supporters of Michael Dukakis were likely to say that civil rights leaders are pushing too slowly. Thus, liberals and conservatives seem to have opposite attitudes.

The results show that being for the Republican candidate tends to go along with being against help for blacks or against the efforts of civil rights leaders. This supports the belief that conservatism is associated with anti-black sentiments, since Eisenman and Sirgo (1991) found a statistically significant tendency for Republicans to be conservatives and Democrats to be liberals. The conservative ideology seems to say that people should take care of themselves, and if blacks are not doing well, tough. This ideology could easily slip into a prejudiced blaming of the victim, by concluding that not only do blacks not deserve governmental help but it is their fault for any problems they have. Such an outlook would ignore the social causes of black poverty in the United States, with all its attendant problems (Eisenman, 1991a).

\section{REFERENCES}

Carmines, E. G. \& Stimson, J. A. (1980). The racial reorientation of American politics. In J. C. Pierce \& J. L. Sullivan (Eds.), The electorate reconsidered (pp. 199-219). Beverly Hills, CA: Sage.

Carmines, E. G., \& Stimson, J. A. (1989). Issue evolution. Princeton, NJ: Princeton University Press.

Eisenman, R. (1991a). From crime to creativity: Psychological and social factors in deviance. Dubuque, IA: Kendall/Hunt.

EISENMAN, R. (1991b). Gender and racial prejudice of conservative college women. Psychological Reports, 68, 450.

EISENMAN, R. (1992). Creativity, social and political attitudes, and liking or disliking David Duke. Bulletin of the Psychonomic Society, 30, 19-22.

EISENmAN, R. (1993). Student attitudes toward David Duke before and after seeing the film "Who is David Duke?'. Bulletin of the Psychonomic Society, 31, 37-38.

EISENMAN, R., \& SiRGo, H. B. (1991). Liberals versus conservatives: Personality, child-rearing attitudes, and birth order/sex differences. Bulletin of the Psychonomic Society, 29, 240-242.

LAPierre, R. (1934). Attitudes and actions. Social Forces, 13, 230-237. RAY, J. J. (1971). Ethnocentrism: Attitudes and behavior. Australian Quarterly, 43; 89-97. 
RAY, J. J. (1976). Do authoritarians hold authoritarian attitudes? Human Relations, 29, 307-325.

RAy, J. J. (1984). Half of all racists are left wing. Political Psychology, 5, 227-235.

Sirgo, H. B., \& Eisenman, R. (1990). Perception of governmental fairness by liberals and conservatives. Psychological Reports, 67, 1331-1334.
Sirgo, H. B., \& EISEnman, R. (1993). Liberals versus conservatives: Are attitudes toward government related to experiences with government? Bulletin of the Psychonomic Society, 31, 155-157.

(Manuscript received January 14, 1993.) 